\title{
МОВОЗНАВСТВО
}

\section{МЕТРИЧНІ КНИГИ - ДЖЕРЕЛЬНА БАЗА ОНОМАСТИЧНИХ ДОСЛІДЖЕНЬ (НА ПРИКЛАДІ ПАРАФІЙ СХІДНОЇ ГАЛИЧИНИ)}

\author{
МАРТА АБУЗАРОВА \\ Університет імені Адама Міцкевича, Познань - Польща \\ KSIECGI METRYKALNE \\ JAKO PODSTAWA ŹRÓDŁOWA BADAŃ ONOMASTYCZNYCH \\ (NA PRZYKŁADZIE PARAFII GALICJI WSCHODNIEJ) \\ MARTA ABUZAROWA \\ Uniwersytet imienia Adama Mickiewicza w Poznaniu, Poznań — Polska
}

STRESZCZENIE. W artykule dokonana została analiza obszernego antroponimicznego oraz toponimicznego materiału, zawartego w księgach metrykalnych parafii we Wschodniej Galicji, który jest wykorzystywany przez językoznawców, historyków, etnologów i innych badaczy. Określona została jego wartość naukowa oraz potencjał informatyczny.

\section{PARISH REGISTERS AS A SOURCE BASE \\ OF ONOMASTIC RESEARCH \\ (BASED ON THE PARISHES OF EASTERN HALYCHYNA) \\ MARTA ABUZAROVA \\ Adam Mickiewicz University in Poznań, Poznań — Poland}

ABSTRACT. The article analyses extensive anthroponymic and toponymic material of parish registers of Eastern Halychyna parishes, which is used by linguists, historians, ethnologists and other groups of scientists in their researches. As a result it defines its scientific value and information potential.

$\mathrm{T}$

радиція ведення метричних книг сягає III сторіччя. Ініціатором їх запровадження, як відомо, виступала церква. До кінця XVII ст. у багатьох країнах Західної Свропи цю функцію бере на себе державна влада ${ }^{1}$. Спроба впровадження церковних метричних книг на теренах сучасної України належить митрополитові Петру Могилі, який у „Требнику” (1646р.) наполягав на тому, щоб кожний парох реєстрував хрещення, одруження й смерть своїх парафіян. На жаль, з багатьох причин ця спроба не увінчалася успіхом.

Наступниками Петра Могили були Антоній Винницький, Йосиф Шумлянський, Варлаам Ясинський. I лише після указів Петра I на українських землях, що вже підпорядковувалися російському законодавству, ведення метрич-

${ }^{1}$ Ф. А. Брокгауз, И. А. Ефрон, Энииклопедический словар, [в:] Электронный ресурс: http://www.vehi.net/brokgauz/index.html 
них книг набуває популярності й облігаторного характеру², а в 1775 р. „метричні книги були визнані державними актами"з.

Якщо аналізувати територію Галичини, то запровадження метричних книг відбувалося вже в XVII - XVIII ст., хоч більшість як римо-католицьких, так і греко-католицьких парафій офіційно почали вести зазначені книги з 1784 року. Це пов'язано $з$ другою метричною реформою австрійського уряду, згідно з якою метрики набували статусу документів громадського стану, а парохи, які вели книги, отримали статус державних службовців. Позитивним фактом для актуалізації потреби ведення метричних книг була постанова австрійського уряду про переписування метричних книг і збереження копій, посвідчених парафіяльним деканатом. Окрім того, був уведений новий зразок метричних книг, що містив відповідні графи. Метричні книги народжень мали такий вигляд: рік, місяць і день народження, номер будинку, ім'я охрещеного, стать, інформація про легальне / нелегальне походження, тобто інформація про те, чи дитина народилася від батьків, які перебувають у шлюбі, чи від неодружених; ім'я і прізвище батьків (стосовно матері найчастіше зазначалося iï дівоче прізвище), їх віровизнання, ім'я і прізвище хресних батьків ${ }^{4}$. Подібний вигляд мали книги реєстрації одружень і смертей. Часто священики робили тут відповідні нотатки, уточнення, вказували соціальний стан чи професію (Nobilis, Filia Vice Directoris Oeconomia Drohobycz). У метричних книгах із записами про смерть інколи зазначали причину (ex apoplexia) або місце смерті (mortuus in Podhorovce) ${ }^{5}$. Вже сама структура записів указує на багатство антропонімного матеріалу.

Останнім часом спостерігаємо виникнення особливого зацікавлення церковними метричними книгами, чимала кількість яких ще не опрацьована і зберігається в архівах. 3 одного боку, зацікавленими $є$ особи, які займаються встановленням родинної генеалогії, а з іншого, - науковці, які використовують матеріал з метричних книг як джерельну базу демографічних, історичних, культурологічних, соціологічних, антропологічних чи ономастичних досліджень.

Грунтовне вивчення різних галузей ономастики не залишило поза увагою церковні метричні книги. Небезпідставно антропонімний матеріал, почерпнутий $з$ церковних метрик, проаналізований у працях таких мовознавців, як П. Чучка ${ }^{6}$, Л. Кравченко ${ }^{7}$ О. Слюсар ${ }^{8}$, Б. Міколайчак ${ }^{9}$ Й. Куць ${ }^{10}$ і ін. Список мовознавців можна продовжити, а це ще раз підтверджує тезу про цінність метричних книг для лінгвістичних досліджень, передусім антропонімічних.

${ }^{2}$ Н. Лобко, 3 історії запровадження метричних книг на українських землях, [в:] „Сумський історико-архівний журнал”, Суми 2010, № 8-9, с. 159.

${ }^{3}$ Д. Антонов, И. Антон ова, Метрические книги России XVIII-начала XX в., Москва 2006, c. 44.

${ }^{4}$ A.Krochmal, M.Proksa, Akta metrykalne w zasobie Archiwum Państwowego w Przemyślu, Przemyśl 1998, s. 6.

${ }_{5}^{5}$ Метрична книга із записами про смерть парафіян м. Дрогобич (римо-католицька) за 17921800 p.p. (Знаходиться в ЦДІАУ у Львові, ф. 201, оп. 4а, спр. 1719). 2005.

${ }^{6}$ П. Чу чка, Прізвища закарпатських украӥнців, [в:] Історико-етимологічний словник, Львів

7 Л.Кравчен ко, Антропонімія Лубенщини, автореф. дис. канд. філол. наук, Київ 2002.

${ }^{8}$ O. Слюсар, Антропонімікон Буковини кіния XVIII - XIX cm. (на матеріалі метричних книг римо-католицької парафії міста Чернівиі 1777-1869 рр.), [в:] „Studia Slovakistica”, Ономастика. Антропонімія, Ужгород 2009, вип. 9, с. 79-83.

${ }^{9}$ B. Mikołaak, Nazwiska w księdze chrztów parafii margonińskiej (pow. Chodzież) z lat 16981761, [в:] „Slavia occidentalis”, тт. 28-29, 1971, s.157-171.

${ }_{10}$ J. Kuć, Antroponimia pogranicza podlasko-mazowieckiego (na podstawie XVII - wiecznych ksiag parafialnych z Mokobód), Siedlce 2011. 
Мета цієї статті - спроба визначення наукового значення антропонімного й топонімного матеріалу метричних книг, з'ясування того, які рубрики й записи $\epsilon$ найважливішими, а які мовознавці використовують як допоміжне джерело.

Об’єктом дослідження стали метрики греко- й римо-католицьких парафій Галичини, зважаючи на їхню поширеність та доступність, хоч загальновідомим є факт про ведення також єврейських, вірменських, протестантських й інших метричних книг.

Опрацьовуючи метричні книги галицьких парафій, що містяться в Центральному Державному Історичному Архіві України у Львові, погоджуємося 3 думкою більшості мовознавців про те, що українська антропонімійна система не була сформована навіть до кінця XVIII сторіччя. Зауважимо, що лише в кінці XVIII - на початку XIX ст. кодифіковане право сприяло стабілізації прізвищ серед найнижчих верств населення, тому система ідентифікації осіб була вже майже сформована. В ній переважає двокомпонентна антропонімна структура: ім’я і прізвищева назва.

Для дослідників антропонімії найбільш інформативними й цікавими $\epsilon$ рубрики, що містять іменування парафіян. Інколи допомагають розділи, де містяться відомості про:

- $\quad$ віровизнання. Особливо важливою ця рубрика $є$ у процесі досліджень власних назв прикордонних територій. Візьмімо, для прикладу, Східну Галичину. Хоч розмовною мовою мешканців цієї території була переважно українська мова, або руська, як іï називали в Австро-Угорщині, все ж таки метричні книги переважно велися польською мовою (інколи латинською). Це пояснюється тим, що наприкінці XVIII - на поч. XIX ст. цю мову номінували як офіційну. Часто трапляються записи українських особових назв польською транслітерацією, що, на жаль, у більшості випадків призводить до їх деформації, на зразок: Ukrainiec ${ }^{11}$, Wasylkiewicz ${ }^{12}$, Wesetowski ${ }^{13}$. Крім того, як зауважують дослідники гуцульської антропонімії, „подання українських антропонімів польською фонографічною системою часто призводило до появи варіантів у написанні одного і того ж антропоніма": Tretiak - Treciak, Hrabczuk-Chrabczuk ${ }^{14}$. Простежуємо й факт латинізації записів, особливо особових імен: Joannes, Theodorus, Gregorius, Catharina ${ }^{15}$. Знаючи віровизнання особи, можна робити припущення про іiі етнічну приналежність, адже до кінця XIX - початку XX ст. етнічну приналежність ототожнювали з віровизнанням. Отже, шляхом відповідних припущень $\epsilon$ шанс віднайти первинну, ще не деформовану особову назву. Хоч думки вчених досі розходяться щодо питання про визначення етнічної приналежності особи на підставі їі родового прізвища, останнім часом з'являється все більше досліджень, які використовують прізвища для визначення генетичної структури населення. У цих дослідженнях на основі аналізу походження прізвища

${ }^{11}$ Метрична книга із записами про хрещчення і одруження греко-католицького парафіяльного уряду в м. Дрогобич с. Задвірне з 1791 по 1800 р. p. Копія, виготовлена в 1838 р. (Знаходиться в ЦДІАУ у Львові, ф. 201, оп. 4 а, спр. 1715).

12 Метрична книга із записами про хрещення греко-католицького парафіяльного уряду в м. Дрогобич з 1812 по 1821 р. p. Копія, виготовлена в 1839 р. (Знаходиться в ЦДІАУ у Львові, ф. 201, оп. 4 a, спр. 1722).

13 Там само.

${ }^{14}$ Б.Близнюк, В. Бірчак, Описові іменування особи в історичних пам'ятках Гуцульщини XV-XIX ст., [в:] Електронний ресурс: http://nbuv.gov.ua/portal/Soc_Gum/Vpu/Fil/2008_19_20/12_ Blyzniuk.pdf

15 Метрична книга із записами про хрещзення греко-католицького парафіяльного уряду в м. Дрогобич з 1812 nо 1821 p. p. Копія, виготовлена в 1839 р. (Знаходиться в ЦДІАУ у Львові, ф. 201, оп. 4 a, спр. 1722). 
доводять, що останні можуть досить точно вказувати на географічне походження носія, адже обсяг прізвищ $є$ великим, а їх поширеність — локальною ${ }^{16}$;

- стать. Метричні книги велися від руки священнослужителями, що змушує розшифровувати відповідний матеріал. Якщо проблема виникає у „відчитуванні" імен, то допоможе графа, в якій міститься запис про стать особи (Юліан - Юлія, Стефан - Стефанія і т. д.). Крім того, рукописні книги $є$ причиною чисельних помилок у метричних записах. Наслідком помилок священнослужителів $\epsilon$, між іншим, наявність різноманітних орфографічних варіантів прізвищ навіть тих осіб, які належать до одного роду. У таких випадках необхідно лематизувати прізвище - знайти його первісну форму. Це непросте завдання для фахівця, яке слід виконувати обережно, щоб не сплутати прізвища різних родів або різних регіонів, що може привести до втрати „географічної інформаціӥ”.

Церковні метричні книги - це не єдине джерело дослідження історичної антропонімії. Подібними до метричних книг є гродські урядові книги, актові книги, різноманітні інвентарі та реєстри, що містять перелік власників нерухомого майна, нотаріальні акти, судові справи і т. д. Сдиною важливою відмінністю $\epsilon$ те, що в цих книгах містяться особові назви переважно представників середнього й вищого суспільних класів (для прикладу, не кожен мешканець мав можливість купувати чи продавати майно). Отже, досліднику важко було б знайти той багатий і місткий антропонімний матеріал, що відображений в метричних книгах, - особові назви різних суспільних класів (особливо соціальних низів), вікових категорій. Про вартість метричних книг лаконічно пише польський мовознавець Ю. Бубак: „Метричні книги містять цікавий матеріал для дослідника народної антропонімії передусім тому, що точно вказують на його географічне розміщення й часові межі, а також тому, що містять матеріал в такій кількості, яку не знайдемо в жодних інших документах і списках"17. Аналіз метричних книг відповідного періоду дає змогу стежити за процесом утворення варіантів одного прізвища або зміни прізвищ протягом кількох років, десятиліть чи навіть століть.

Як зазначають дослідники, „імена людей — частина історії народів. В них відображені побут, вірування, надії, фантазія й художня творчість народів, їхні історичні контакти. Для того, щоб певне ім'я з'явилося у відповідного народу, необхідні певні культурно-історичні умови. Тому багато імен - це яскравий відбиток відповідної епохи"18. Саме тому антропонімний матеріал, почерпнутий з метричних книг і проаналізований лінгвістами, може бути використаний також іншими дослідниками, зокрема істориками - 3 метою вивчення історії певного населеного пункту чи території; етнологами - для вивчення культури, побуту етнічної групи або цілого народу (як зазначає М. Худаш, найінформативнішими в цьому аспекті постають особові назви, „дані людям за їх соціальною приналежність, професією чи якимсь заняттям" ${ }^{19}$ ); правознавцями, для яких особові назви є об'єктами вивчення історії права, права звичаєвого; соці-

${ }^{16}$ P. Darlu, G. Brunet, D. Barbero, Spatial and Temporal Analyses of Surname Distributions to Estimate Mobility and Changes in Historical Demography: The Example of Savoy (France) from the Eighteenth to the Twentieth Century, [w:] źródło elektroniczne: http://bu169.bu.amu.edu.p1/han/Springe rEbooksHumanitiesSocialSciencesLaw/www.springerlink.com/content/g14q2p88v3jm670h/fulltext.pdf

17 J. Bubak, Nazwiska ludności dawnego starostwa nowotarskiego, Komitet Językoznawstwa

Polskiej Akademii Nauk, Wrocław, Zakład Narodowy imienia Ossolińskich, 1970, c. 21.

18 А. Суслова, А. Суперанская, О русских именах, Ленинград 1991, ч. 1, с. 3-4.

${ }^{19}$ М. Худаш, 3 історії украӥнської антропонімї, Київ 1977, с. 14. 
ологами й соціальними психологами - для вивчення родинних стосунків, психології народу; дослідниками генеалогії, які звератаються до питань походження й історії знаних родів чи осіб; соціогеографами, які досліджують питання географії культури, географії релігії, географії розселення й поселення, географії міграцій та ін.

Не вважаємо за потрібне у цій статті детально аналізувати роль антропонімії для мовознавства й науки загалом, адже ці питання є предметом досліджень праць багатьох науковців, зокрема М. Худаша ${ }^{20}$, К. Добровольского ${ }^{21}$ й ін.

Безперечно, матеріал, що міститься в церковних метричних книгах має більшу цінність для досліджень 3 антропонімії, ніж топонімії. Значно менше інформації $з$ метричних книг може отримати дослідник топонімії: це найчастіше територіальні назви населених пунктів, звідки й походить дана книга, а також частини населеного пункту — мікротопоніми, що зазвичай указуються разом із даними про особу.

Ще однією причиною зацікавлення метричними книгами дослідників топонімії $є$ антропонімікон певної території, що нерідко служив відповідним джерелом у період формування географічних назв. Відомо, що багато топонімів - це відантропонімні деривати. Місцеві назви (крім назв населених пунктів, також назви вулиць, майданів, парків), утворені від імен, прізвищ чи прізвиськ власників землі, засновників населеного пункту або пересічних мешканців, розповсюджені також в топонімії Галичини: с. Кульчиці, с. Іванів, м. Августів (пол. Augustów) - тепер Великі Мости, м. Кам'янка-Струмилівська (пол. Kamionka-Strumiłowa) — тепер Кам’янка-Бузька й інші.

Отже, потенціал церковних метрик надзвичайно великий: обсяг, достовірність і цілісність антропонімного матеріалу дають змогу аналізувати як окремі антропонімні одиниці, так і загальну антропонімну картину в діахронічному й синхронічному аспектах.

${ }^{20}$ Там само.

${ }^{21} \mathrm{~K}$. Dobrowolski, Znaczenie metryk kościelnych dla badań naukowych, Rocznik Towarzystwa Heraldycznego we Lwowie, Lwów 1920, т. V, s. 90-110. 